I had long been in Professor Coulson's debt for his little undergraduate book on Waves; but my personal acquaintance with him began when he agreed to become the first president of the Association's Oxford and District Branch. That his opening address drew a large and appreciative audience caused us no surprise; and one might have expected that, for such a busy and distinguished person, that was where his contribution would end. Far from it-he was more than generous in giving his time to the young Branch, chairing almost every meeting during the year and helping us over many of our early problems.

The following September I asked him whether he thought it was possible to get across something of the flavour of wave mechanics to sixth formers. His reply was completely in character: "I don't know, but I would love to try ... I'm afraid I haven't a free day up to 14 March; could I come on the 15 th ?" It was, of course, a superb lecture-thoughtfully prepared and beautifully delivered.

When I last spoke to him, it happened that we were both visiting Tanzania -he as Royal Society Visiting Professor to the (then) University of East Africa. The leanness of his figure was enhanced by tropical dress of white shorts and shirt. As we listened together to a talk on African birds, he was in his element; a few months short of 60 at the time, he was about to set off to climb Kilimanjaro.

It was typical that, as President of the Association in 1969, he should choose to entitle his address "On liking mathematics". From that personal manifesto (printed in full in the Gazette for October of that year) I have selected one sentence to end this appreciation; he was speaking in the context of mathematical proof, but for me it sums up Charles Coulson the man: "Certainly you should put your Q.E.D. at the end."

D. A. QUADLING

\title{
Norman de Quetteville Dodds
}

After graduating with first class honours in Mathematics from King's College, London, Norman Dodds took up a teaching appointment at Highbury County Grammar School, where he remained until 1944 when he moved to Bishophalt School in Middlesex. Eight years later he went to Haberdashers' Aske's School at Hampstead, where he remained until his retirement in July 1970. Previous to going to King's he had spent some 8 years in the commercial world, an experience which stood him in good stead in his teaching career.

He was a many-sided person. As a sportsman he took a great interest in the athletic activities in all the schools in which he taught, and was himself a first-class cricketer. He had been a keen scout and motorcyclist and was ever a keen gardener. During the war, when his school was evacuated to Somerset, he helped with harvest camps for the boys, and was a constant 
source of strength and guidance to many boys who were perforce separated from their parents. During these war years he also worked as a member of an ambulance team in Somerset and helped with the formation of an Air Training Corps Flight in the school in 1941. His other great interest was music and he was, for 21 years until his death, a very active and devoted member of his local church and a constant performer with the Royal Choral Society.

For many years until his death he was a chief examiner in Mathematics for the Northern Universities Joint Matriculation Board. A life member of the Mathematical Association, he attended regularly at the Annual Conferences as treasurer and member of the Diploma Board and as a member of the Council, thus contributing much in time and experience to the Association. For some years he was the energetic secretary of the London Branch and then its chairman, and during this period he organised several successful meetings in London. He became a member of the Institute of Mathematics and its Applications on its formation.

I first met him when he joined Highbury School, and over the years our friendship grew and matured. He was an ever-cheerful and loyal companion, never ruffled, completely reliable and unsparing of himself in his efforts to promote and enlarge the activities of any organisation with which he was connected. He was a tireless worker and his example of service is one to be emulated; he will be sadly missed for many a long day, not only by the family whom he adored, but by his many friends and all who knew him.

B. J. F. DORRINGTON

\section{Vincenzo Consolato Antonino Ferraro}

Professor V. C. A. Ferraro died unexpectedly on January 4, 1974 at the age of 66 while he was Professor of Mathematics at Queen Mary College, London. Members of the Mathematical Association will remember that he was its President for the year 1962/63. His research work in hydromagnetics and solar-terrestrial relationships and his interests in the arts have been described elsewhere; this brief notice concerns his views on the teaching of mathematics.

Ferraro, as his research work would lead one to expect, stressed the importance of the teaching of electromagnetics. But he attached equal importance to instruction in classical mechanics. In his student days between the wars, this subject had come to be under-estimated in competition with the fashionable topics of quantum mechanics and relativity. Experience showed him, as it did to other applied mathematicians, that this was an error, as one example among many will show. The present-day exploration of the solar system by spacecraft necessitates a thorough knowledge of classical mechanics and of Newtonian gravitation, without which the orbits of these vehicles cannot be calculated. 